\title{
Analysis of the Socio-environmental Management of Covid 19 in Perú
}

\author{
Sandra Cueto $^{1}$, Jorge Ferrer $^{1}$, Alvaro Guevara ${ }^{1}$, and Yensy Segovia ${ }^{1 *}$ \\ ${ }^{1}$ Professional Academic School of Environmental Engineering, Universidad Continental, Huancayo, 12001 Perú
}

\begin{abstract}
The objective of this article is to analyze the management of Covid-19 from a socio-environmental perspective, with a scientific, holistic and adaptive approach. On March 16 of 2020, the Peruvian government began to implement measures to slow the spread of the virus and allow time to strengthen the public health system and after 9 months the results have placed the country among the first places in the mortality rate world level. The basic lines of action of the Peruvian government have been focused on: reducing crowds, stocking up with hospital supplies and detecting infected. However, we identified that the actions corresponding to such basic lines lacked scientific support, were academically biased and inappropriate to the context. Our analysis has been accompanied by proposals that should have been applied in the initial phase of the proliferation of the virus, each of these proposals are designed based on scientific interdisciplinarity and adapted to the geographical and cultural heterogeneity of Peru. It is concluded that decision making must be in accordance with the different realities of the country and that since it is a diverse country, these decisions must be approached seeking the benefit of the entire population.
\end{abstract}

\section{Introduction}

On January 7 of 2020, China declares to have discovered the cause of the disease and calls it Wuhan Coronavirus. On March 11 of 2020, the director of the World Health Organization-WHO, Tedros Adhanom declared the new coronavirus a pandemic [1].

Until December 15 of 2020 there are 36754 deaths and 986130 infected [2] Peru has the second highest death rate per million inhabitants in the world. It is visible that many of the governments measures have not withstood the rigor of scientific analysis, for this reason it was decided to propose socio-environmental management proposals based on the characteristics of the socioecological systems and that should have been implemented before and during the arrival of Covid-19 to Peru, to control the proliferation of the virus in the country and reduce negative socioeconomic impacts.

The proposals had to be presented to the Peruvian population between January 21 and the first days of February, since on those dates the first cases of Covid-19 were reported in Europe. The objective is to contain the spread of the virus and avoid a total quarantine, since $75 \%$ of the economically active population in Peru is informal [3], so paralyzing the economy is not something feasible for our country.

\section{Methodology}

The proposals arise from the analysis of socioecological systems-SES analysis to which Elinor Ostrom, Nobel Prize in Economics in 2009, contributed decisively. This methodology helps in the analysis of the variables that are part of a holistic framework to approach the understanding of complex and multilevel systems, allowing decision makers at some level of government to carry out integrated management of specific problems in a socioecological context [4]. Table 1 is the network of variables and sub variables to analyze a socioecological system.

We selected the SES framework as a tool to diagnose the sustainability of socioecological systems because it provides a systematic and comprehensive method to define attributes of that system and to identify those that may be associated with outcomes of interest. To build a classification system that identifies significant variables that influence the management of the coronavirus in Peru.

Interdisciplinary approaches that integrate socioeconomic data with information from the public health system have rarely been used to understand the links between health factors and outcomes of government decisions.

In this analysis we highlight some variables, which were developed by Elinor Ostrom, which have not been considered by the management of the national government and will therefore be the basis for these proposals.

\section{Proposals}

Socioecological systems, due to their social and ecosystem dimensions, are characterized by being complex, multivariable, non-linear, multi sectoral and in constant change. Due to these characteristics, optimal socio-environmental management must be holistic and interdisciplinary [4], it requires that policy makers adopt a learning process, instead of imposing final solutions and that it be an adaptive management in time and in the space [5].

The proposals described below were conceived taking into account the characteristics of an optimal socioenvironmental management and to be applied in the time interval between January 21 and the first days of February 2020.

\footnotetext{
* Corresponding author: 74163042@continental.edu.pe
} 
Table 1. Network of variables and subvariables to analyze a socioecological system. Fuente: Ostrom 2007

\begin{tabular}{|c|c|}
\hline \multicolumn{2}{|c|}{ Social, Economic, and Political Settings (S) } \\
\hline \multicolumn{2}{|c|}{$\begin{array}{c}\text { S1- Economic development. S2- Demographic trends. S3- Political stability. S4- Government } \\
\text { settlement policies. S5- Market incentives. S6- Media organization }\end{array}$} \\
\hline Resource System (RS) & Governance System (GS) \\
\hline RS1- Sector (e.g., water, forests, pasture) & GS1- Government organizations \\
\hline RS2- Clarity of system boundaries & GS2- Non-government organizations \\
\hline RS3- Size of resource system & GS3- Network structure \\
\hline RS4- Human-constructed facilities & GS4- Property-rights systems \\
\hline RS5- Productivity of system & GS5- Operational rules \\
\hline RS6- Equilibrium properties & GS6- Collective-choice rules \\
\hline RS7- Predictability of system dynamics & GS7- Constitutional rules \\
\hline RS8- Storage characteristics & GS8- Monitoring \& sanctioning processes \\
\hline \multicolumn{2}{|l|}{ RS9- Location } \\
\hline Resource Units (RU) & Users (U) \\
\hline RU1- Resource unit mobility & U1- Number of users \\
\hline RU2- Growth or replacement rate & U2- Socioeconomic attributes of users \\
\hline RU3- Interaction among resource units & U3- History of use \\
\hline RU4- Economic value & U4- Location \\
\hline RU5- Size & U5- Leadership/entrepreneurship \\
\hline RU6- Distinctive markings & U6- Norms/social capital \\
\hline \multirow[t]{3}{*}{ RU7- Spatial \& temporal distribution } & U7- Knowledge of SES/mental models \\
\hline & U8- Dependence on resource \\
\hline & U9- Technology used \\
\hline \multicolumn{2}{|c|}{ Interactions (I) ----> Outcomes (O) } \\
\hline $\begin{array}{l}\text { I1- Harvesting levels of diverse users } \\
\text { I2- Information sharing among users }\end{array}$ & $\begin{array}{l}\text { O1- Social performance measures (e.g., } \\
\text { efficiency, equity, accountability) }\end{array}$ \\
\hline $\begin{array}{l}\text { I3- Deliberation processes } \\
\text { I4- Conflicts among users }\end{array}$ & $\begin{array}{l}\text { O2- Ecological performance measures (e.g., } \\
\text { overharvested, resilience, diversity) }\end{array}$ \\
\hline I5- Investment activities & O3- Externalities to other SESs \\
\hline \multicolumn{2}{|l|}{ I6- Lobbying activities } \\
\hline \multicolumn{2}{|c|}{ Related Ecosystems (ECO) } \\
\hline ECO1- Climate patterns. ECO2- Polluti & terns. ECO3- Flows into and out of focal SES \\
\hline
\end{tabular}

In this study we have highlighted a set of variables and sub variables that we consider relevant, linking them with the available data on the social and economic characteristics of Peru.

The sub variables used are detailed below:

- Within the Resource System variable, the sub variables were used:

RS1 = Water (refers to access to drinking water)

RS4 = Human constructed facilities (based on the capacity and availability of hospitals and hotels)

- Within the government system variable, the sub variables were used:

GS1 = Government organizations (state institutions such as the Peruvian Navy and the "Universidad Nacional de Ingeniería”)
GS2 = Non-governmental organizations (private sector institutions "Universidad Peruana Cayetano Heredia") GS7 = Constitutional rules (official name of the 2020 constitutional year and the constitutional reform regarding the universal right of access to water)

- Within the Resource Units variable, the sub variables were used:

RU5 = Size (number of medical devices, Intensive Care Units-ICU beds and diagnostic tests)

- Within the variable users, the sub variables were used: $\mathrm{U1}=$ Number of users (number of patients per ICU beds, repatriated citizens and number of households in Peru) $\mathrm{U} 2=$ Socioeconomic attributes of the users (access to the public water network according to the area of residence) U4 = Location (territorial identity)

- Within the results variable, the sub variables were used: 
$\mathrm{O} 1=$ Social Performance Measures (number of repatriated passengers)

\subsection{Acquisition of medical and hospital devices}

The 9\% of Gross Domestic Product-GDP (25 million dollars) was allocated to the health sector, to strengthen prevention, control and response systems against Covid19 [6]. However, the expenditure was destined for the purchase of medical and hospital devices (personal protective equipment, diagnostic tests, electromechanical equipment, drugs, disinfectant material and beds in the intensive care unit) that arrived late, in insufficient quantities and in many cases did not reach health facilities, there were also useless purchases, as in the case of serological tests (rapid tests for Covid-19) that did not help to quickly detect those infected.

The acquisition of medical and hospital devices had to be carried out as a priority, as soon as there was knowledge of the spread of the virus outside the Asian borders. Likewise, the objective at the beginning of 2020 should have been the strengthening of the public health system with the appropriate distribution of medical and hospital devices, most of which had to be imported initially, allowing time for the national industry to meet a demand that was it would grow in the following months.

When monitoring the operationalized SES variables in the analysis of the socio-environmental management of Covid-19 in Peru, there was no evidence of correlation between the constitutional norms (GS7), represented in this case by the official name of the year 2020 "Year of the universalization of health" [7], with the availability of beds in the ICU (RU5), nor with the application of molecular tests (RU5). The average monthly number of patients in ICU beds was obtained by dividing the 37000 deceased by 9 months after the Covid-19 [2], resulting in 4111 potential patients per month (U1). However, the number of beds available in the ICU throughout the country is 1469 , that is the demand was never met. On the other hand, considering the importance of molecular tests in the detection of people who carry the virus, we find that there is an alarming disproportion between the 5 233346 rapid tests and the 1242189 molecular tests (RU5) [8], that is, a ratio of 4 to 1 . Finally, a measure of the social performance (O1) of the Covid-19 management is the number of deaths per million inhabitants, which in the Peruvian case is 1110 , the second highest figure in the world [9].

\subsection{Management of international social displacement}

The closure of the Peruvian borders was carried out on March 17 of 2020, which caused some passengers to be stranded outside Peru, for which a repatriation plan should have been executed establishing health protocols accompanied by a molecular test. Taking into account the aforementioned, the borders had to be closed as of January 21 and establish a period of 10 days for those who need to travel.
It is worth mentioning that Peru has 11 international airports [10], including Lima, where almost $1 / 3$ of the Peruvian population is concentrated, this being one of the main sources of infection for which passengers had to be segregated using the available airports.

When monitoring the operationalized SES variables in the analysis of the socio-environmental management of Covid-19 in Peru, the criterion of taking into account the cities with the highest number of facilities built by humans (RS4) was not considered for the selection of places for the return of returnees, facilities such as hospitals and hotels.

The main cities that have these infrastructures are Lima with a total of 206 hospitals and a hotel capacity that can accommodate 123177 people; the city of Cusco has 20 hospitals and a hotel capacity that can house 47711 people while the city of Arequipa has 24 hospitals and a hotel capacity that can house 30181 people [11]. These facilities should have been sufficient to satisfy the number of users or returnees (U1), which were approximately 30 000 people [12], characterized by having a territorial identity or location affinity (U4) in Peru (born in Peru, residents or with relatives within the national territory).

As a measure of social performance (O1) left by the Peruvian government, 30000 citizens were repatriated over 5 months [12]. In other words, there was an underutilization of the installed capacity to safely house the returnees and a delay in the repatriation process.

\subsection{Management of social displacement at the national level}

The Political Constitution of Peru [13] in article 2,11 says that: "Everyone has the right to choose their place of residence, to transit through the national territory and to leave and enter it, except for limitations for reasons of health or due to judicial order or by application of the immigration law". Free transit through Peruvian territory can be restricted for health reasons.

Lima has more passenger traffic in interprovincial transport [14] so preventing interprovincial transport caused thousands of Peruvians to not be able to return to their place of origin and that people who had to travel to the capital for medical treatment were left stranded. Therefore, it is proposed that people who wish to return to a city in the interior of the country register in a registry, so that they can take a molecular test that detects the presence of the virus in the patient [15]. Each passenger who is going to travel and who is going to leave the cities of Lima, Arequipa, Cusco, Chiclayo, Trujillo, Pisco, Piura, Talara, Iquitos, Juliaca and Tacna must go through this test since these cities have an international airport.

The time it takes for the results to be released, the passenger must isolate himself to avoid contagion, for that the Pan American Village can be made available in the case of the city of Lima, which is a large departmental complex, which has capacity For 9500 users and in the other cities the different hotels can be used, the Peruvian State is the one that must take charge of both the molecular test and the stay of the people. 
The control of interprovincial roads should have been in charge of the Ministry of Health-MINSA, Superintendence of land transportation of people, cargo and merchandise-SUTRAN and of the National Police of Peru-PNP, in order to improve the control of uninfected passengers.

\subsection{Encourage the initiatives of civil organizations and the state}

The organic law of the base of decentralization, Law No. 27867 indicates that regional governments can be autonomous so that they develop strategies that do not affect the sustainability of families and that of small, medium and large companies [16]. Ensuring the transparency of the development of these strategies, the central government (the highest level of government of the Executive Branch) had to negotiate agreements with civil organizations and the State (Non-Governmental Organization-NGO, churches, Armed Forces, Universities) to promote projects that provide social aid together to regional governments, and under the supervision of the National Superintendency of Customs and Tax Administration-SUNAT [17]. According to the Peruvian Agency for International Cooperation-APCI annual report for 2017 there are 2334 registered entities [18]. It is proposed that the Government of Peru support logistics and economically so that the initiatives reach the population that needs it.

The analysis of the socio-environmental management of Covid-19 in Peru was carried out from the monitoring of the operationalization of the SES variables; in this sense, the Government of Peru did not consider the initiatives of governmental organizations (GS1) as the Peruvian Navy who built and delivered artificial respirators to Naval Hospital, these respirators were called "Samay" [19]. There is also the initiative of the "Universidad Nacional de Ingeniería" (GS1) where a research team designed "VentUNI" which is a complementary device to the non-invasive oxygenator [20]. The initiatives of non-governmental organizations (GS2) were also not considered, such as the "Universidad Peruana Cayetano Heredia" where the molecular biologist Edward Málaga together with his research team, they developed a rapid molecular test using spittle samples to detect the coronavirus [21]. Finally, the amount of population (O1) that could benefit from the industrial production of respirators could have reduced the 37000 deaths over the 9 month pandemic [2] and from the industrial production of rapid molecular tests the 5233 346 rapid tests purchased by the Government of Peru [8] could have been replaced to increase the efficiency in the detection of virus transmitters.

\subsection{Classes closure based on contagion by province}

Education in Peru is the most prioritized fundamental right, with more than 9,9 million Peruvian students according to the census of the National Institute of Statistics and Informatics-INEI [22]. The objective is to close the educational gap in Peru, there are still unavoidable challenges due to the reality of the country, there is a clear margin of difference in access to the different media since according to the INEI, only $39 \%$ of households national level has internet access and in rural areas only $5 \%$ [23].

It is proposed that the country educational institutions suspend normal classes according to the number of Covid19 infections that exist in each region, having proposed as an initiative a focused teaching model according to the regional scope, which by competence corresponds to regional governments and ministries.

Article 36 of the organic law of the decentralization base No. 27 867, establishes and regulates the structure, organization, powers and functions of regional governments and ministries [16]. One of the shared functions is the "Education and management of educational services of initial, primary, secondary and higher non-university level, with intercultural criteria aimed at promoting training for development".

If a focused or distance learning model had been proposed with the availability of technological means to allow education to be carried out in person or virtual in cities, according to the risk analysis report of each region. The risk of contagion in rural areas is lower than in urban areas, due to population density. Teaching positions in rural areas are occupied by professionals who are generally not residents of the area, the transfer of teachers from outside the rural areas in a health emergency should have been given with the logistics that the Armed Forces have mobility, lodging and even food, complementing the already well known facilities that native or peasant communities provide to the teachers who work there.

\subsection{Implement security measures in transportation systems}

According to the census carried out in 2017 by the INEI [24] the transport sector employs more than 1,2 million people, which is why this sector was affected by a pandemic.

When this service was closed, there was a considerable rate of unemployed people which caused society to see the need to develop autonomous activities without complying with any type of preventive measure, that is why the transport units had to take the following measures to adapt this proposal would have entered into force 10 days after the first case of Covid-19 was known in Peru.

- Increase transport units, generating employment in addition to giving more options for users to travel, respecting the social distancing of one meter as recommended by the WHO, for that it is necessary for transport units to reduce their capacity, on the basis of this absence of passengers by $50 \%$ with the increase in tickets so that the transport unit does not need to complete its capacity and respect this guideline, in addition to allowing the unit to access services such as periodic fumigation and the acquisition of personal protective equipment. 
- According to the studies carried out by Van Doremalen, the virus can remain in copper for up to 04 hours [25], considering that the coins are composed of the alloy of this metal and other minerals, it would be appropriate to avoid spreading the virus by means of coins, using virtual collection applications that allow payment to be made through the QR code [26] in such a way that there is no contact, but in the case of the population that does not have an electronic device, they will still be able to make the payment with coins since the transport collectors will follow a sanitary protocol to carry out the payment transaction.

\subsection{Supply of hygiene kits and drinking water}

Between 7 and 8 million Peruvians do not have access to drinking water [27]. One of the difficulties is the economic gaps that exist to obtain drinking water, which affect families with fewer resources.

A study revealed that on average the families of human settlements consume 3,9 cubic meters of water per month for which they pay about 88 soles [28], due to this problem it is proposed that the Peruvian Government supply water by means of tanker trucks accompanied of personal hygiene kits, since this is essential to be able to contribute to limiting the spread of the virus, for this, kits would be delivered that would include: soaps, plastic bucket with dispenser and hermetic seal, bottle with alcohol and disinfectant cloths.

Previously, it was mentioned that the Peruvian Government should have agreements with organizations (NGOs, churches, universities and the armed forces), so the government should assign them a budget for the acquisition of kits which would be distributed by those in charge of these organizations. The toilet kits should be distributed to $28 \%$ of the rural population that still does not have water service from the public network [29].

When monitoring the operationalized SES variables in the analysis of the socio-environmental management of Covid-19 in Peru, the lack of drinking water resource (RS1) is shown in certain sectors of the national territory, despite what is established in the constitutional rules (GS7) Law No. 30588 "Law of constitutional reform that recognizes the right of access to water as a constitutional right" [30]. The number of potential users (U1) that should have access to the public network is 8252284 households [31] and according to their socioeconomic attribute (U2), $87,8 \%$ of the urban sector and $72 \%$ of the rural sector have access to water supply through the public network [29]. However, as a measure of social performance $(\mathrm{O} 1)$, the efforts made by the government managed to provide access to drinking water to only $67,4 \%$ of households [32]. That is to say, the lack of drinking water for a significant sector of the population was a disadvantage in reducing the transmission of the virus.

\section{Conclusions}

After analyzing the management of the Peruvian Government against Covid-19, it is concluded that the decision making should be developed based on an academic scientific perspective, such as the analysis of socioecological systems for optimal socioenvironmental management. In this way, human freedoms in the country would have been prevented from being violated due to an inefficient quarantine that affected all productive sectors, ceasing to produce 30000 million dollars in 3 and a half months of economic paralysis that mainly affected $75 \%$ of the economically active population which is informal.

The proposals can be used as a background since it is part of continuous learning, however, the measures to be taken in the future must be appropriate to the situation of time and space, trying to involve different disciplines that are related and have a scientific basis.

Prevention is the best measure to avoid extreme situations such as those faced by Peru, having bought security implements for the health sector and molecular testing before the arrival of Covid-19, closing the borders and controlling the entry of Peruvians to prevent the virus from entering to Peru, restricting interprovincial transit to the interior of the country, preventing proliferation throughout the national territory by testing people who wanted to return to their cities of origin, giving autonomy to regional governments to manage the health measures and regulations for economic and productive activities that are appropriate to its jurisdiction, avoiding the suspension of normal classes, mainly in rural areas, doubling the number of vehicles, avoiding the generation of infectious sources and guaranteeing access to water drinkable to all Peruvians to maintain hygiene and cleanliness, it could have been control the proliferation of the virus avoiding the suspension of economic activities.

An optimal socioenvironmental management is characterized by a holistic approach to the problem and therefore the interdisciplinary nature is essential, as well as constant learning and adaptation to the dynamics of the socioecological system. The proposals put forward in this article respond precisely to the characteristics of an optimal socioenvironmental management and should be established in a preventive manner, being essential to apply them in the initial phase of the proliferation of the virus, considering the possibility of new epidemics reaching Peru.

\section{References}

1. OMS, Nuevo coronavirusChina, https://www.who.int/csr/don/12-january2020-novel-coronavirus-china/es/ (2020)

2. MINSA, Sala situacional COVID19 Perú, https://covid19.minsa.gob.pe/sala_situacio nal.asp (2020)

3. N. LIARES, Informalidad laboral en el Perú, la gran problemática y sus posibles soluciones, https://economica.pe/informalidadlaboral-peru/ (2020)

4. E. OSTROM, Adiagnostic approach for going beyond panaceas, p. 15181-15187, DOI 10.1073/pnas.0702288104. (2007)

5. D. KORTEN, Community Organization and Rural Development. A Learning Process Approach. Public 
Administration Review. Vol. 40, no. 5, p. 480. DOI 10.2307/3110204 (1980)

6. BBC, Coronavirus: los 10 países que más han gastado en enfrentar la pand emia (y cómo se ubican los de América Latina), https://www.bbc.com/mundo/noticias52686453 (2020)

7. GOBIERNO DEL PERÚ, Declaran el año 2020 como el “Año de la Universalización de

la Salud", https://busquedas.elperuano.pe/download /url/declaran-el-ano-2020-como-el-ano-de-launiversalizacion-de-decreto-supremo-n-002-2020pcm-1844389-1 (2020)

8. PERÚ

COMPRA, Detalle de contrataciones https://www. perucompras.gob.pe/contrataciones/contratacionesemergencia-covid19.php (2020)

9. WORLDOMETER, COVID-19 CORONAVIRUS PANDEMIC, https://www.worldometers.info/coron avirus/ (2020)

10. MTC, La importancia de la infraestructura para mejorar la conectividad aérea, 4 , https://www.mincetur.gob.pe/wpcontent/uploads/documentos/turismo/eventos_capa citaciones/Primer_Foro_Internacional_de_Facilitaci on_Turistica/Lunes_26_junio/Bloque_III/2.La_imp ortancia_de_la_infraestructura_para_mejorar_la_co nectividad_aerea_MTC.pdf, (2020)

11. Compendio Estadístico Perú, https://www.inei.gob.pe/media/M enuRecursivo/publicaciones_digitales/Est/Lib1635/ cap22/ind22.htm , (2018)

12. GESTIÓN, Perú suspende vuelos humanitarios por readaptación de aeropuerto. https://gestion.pe/peru/peru-suspendevuelos-humanitarios-por-readaptacion-deaeropuerto-noticia/ (2020)

13. GOBIERNO DEL PERÚ, Constitución política del Perú, http://www.pcm.gob.pe/wpcontent/uploads/2013/09/Constitucion-Política-delPeru-1993.pdf , 3 (1993)

14. MTC, Estadística Servicios de Transporte Terrestre por Carretera Servicios de Pasajeros, https://www.gob.pe/institucion/mtc/infor mes-publicaciones/344888-estadistica-servicios-detransporte-terrestre-por-carretera-servicios-depasajeros (2020)

15. OMS, Pruebas diagnósticas para el SARS-CoV2, https://apps.who.int/iris/bitstream/handle/10665/ 335830/WHO-2019-nCoV-laboratory-2020.6spa.pdf (2020)

16. CONGRESO DE LA REPÚBICA DEL PERÚ. Ley Orgánica de Gobiernos Regionales, https://sinia.minam.gob.pe/normas/leyorganica-gobiernos-regionales (2003)

17. CONGRESO DE LA REPÚBLICA DEL PERÚ, Ley que autoriza a la Superintendencia Nacional de Aduanas y de Administración Tributaria (SUNAT) a la creación de una intendencia y fiscalización de las organizaciones sin fines de lucro. http://www.leyes.congreso.gob.pe/Document
os/2016_2021/Proyectos_de_Ley_y_de_Resolucion es_Legislativas/PL0333220180911.PDF (2018)

18. CONGRESO DE LA REPUBLICA, Regulación sobre supervisión de actividades y financiamiento de los organismos no gubernamentales, http://www2.congreso.gob.pe/sicr /cendocbib/con5_uibd.nsf/994910FB432068F2052 5833F00634CBF/\$FILE/REGULACIÓN_SOBRE_ SUPERVISIÓN_DE_ACTIVIDADES_Y_FINAN CIAMIENTO_N_19.pdf (2018)

19. MARINA DE GUERRA DEL PERÚ. Hospital Naval recibe diez respiradores artificiales desarrollados por la Marina de Guerra del Perú. http://www.marina.mil.pe/en/noticia/hospitalnaval-recibe-diez-respiradores-artificialesdesarrollados-por-la-marina-de-guerra-delperu (2020)

20. UNI, Crean novedoso "VentUNI", dispositivo complementario al oxigenador no invasivo. https://vri.uni.edu.pe/uni-crean-novedosoventuni (2020)

21. UNIVERSIDAD PERUANA CAYETANO HEREDIA. Científico de la Cayetano logra prueba rápida molecular para detectar Coronavirus. https://investigacion.cayetano.edu.pe/ prensa/250-cientifico-de-la-cayetano-logra-pruebarapida-molecular-para-detectar-coronavirus (2020)

22. MINEDU, Minedu comprará más de 840 mil tablets con internet móvil Para escolares de zonas

alejadas. https://www.gob.pe/institucion/minedu/no ticias/126152-minedu-comprara-mas-de-840-miltablets-con-internet-movil-para-escolares-de-zonasalejadas (2020)

23. LOGROS PERÚ, Situación actual de la educación en el Perú frente al coronavirus. https://logrosperu.com/blog/actualidad /situacion-actual-de-la-educacion-en-el-peru-frenteal-coronavirus-2890 (2020)

24. EL COMERCIO, Más del $80 \%$ de trabajadores del sector transportes son informales, https://elcomercio.pe/economia/peru/ip e-fiori-inei-informalidad-transportes-80trabajadores-sector-transportes-son-informalesnoticia-624380-noticia/ (2020)

25. L. LAGOS. ¿Cuánto permanece el coronavirus en el aire $y$ otras superficies?, https://ladiaria.com.uy/ciencia/articulo /2020/3/cuanto-permanece-el-coronavirus-en-elaire-y-otras-superficies/ (2020)

26. RCR PERÚ, Coronavirus: Aplicación móvil permitirá cobrar pasaje de buses y combis. https://www.rcrperu.com/coronavirusaplicacion-movil-permitira-cobrar-pasaje-de-busesy-combis/ (2020)

27. OXFAM, Entre 7 y 8 millones de peruanos no tienen acceso a agua potable. https://peru.oxfam.org/qu\%C3\%A9hacemos-ayuda-humanitaria/entre-7-y-8-millonesde-peruanos-no-tienen-acceso-agua-potable (2020)

28. SUNASS, SUNASS: comprar agua por camión cisterna les cuesta a las familias limeñas 72 soles 
mensuales. http://www.sunass.gob.pe/websunass/in dex.php/noticias/item/568-sunass-comprar-aguapor-camion-cisterna-les-cuesta-a-las-familiaslimenas-72-soles-mensuales. (2015)

29. INEI, Anuario de estadísticas ambientales 2019, https://www.inei.gob.pe/media/MenuRecursi vo/publicaciones_digitales/Est/Lib1704/libro.pdf (2 019)

30. GOBIERNO DEL PERÚ, Ley de reforma constitucional que reconoce el derecho de acceso al agua como derecho constitucional, https://busquedas.elperuano.pe/dow nload/url/ley-de-reforma-constitucional-quereconoce-el-derecho-de-acc-ley-n-30588-15360041 (2017)

31. INEI, Características de las viviendas particulares y los

hogares, https://www.inei.gob.pe/media/MenuRecu rsivo/publicaciones_digitales/Est/Lib1538/Libro.pd $\underline{f}(2017)$

32. INEI, Perú en cifras, https://www.inei.gob.pe, (2020) 